\title{
PENGARUH KEMITRAAN TERHADAP KONDISI SOSIAL EKONOMI PETANI DAN LEMBAGA MITRA (SUATU KASUS DI ASOSIASI ASPAKUSA MAKMUR)
}

\author{
Maria Winanda Wulandari ${ }^{\left.{ }^{*}\right)}$, Hendrik Johannes Nadapdap ${ }^{1)}$ \\ ${ }^{1}$ Universitas Kristen Satya Wacana, Indonesia \\ ${ }^{*}$ Corresponding author : mariawinandawulan@gmail.com
}

To cite this article:

Wulandari, M., \& Nadapdap, H. (2020). Pengaruh Kemitraan Terhadap Kondisi Sosial Ekonomi Petani dan Lembaga Mitra (Suatu Kasus di Asosiasi Aspakusa Makmur). JIA (Jurnal Ilmiah Agribisnis) : Jurnal Agribisnis dan IImu Sosial Ekonomi Pertanian, 5(3), 84 - 92. doi:http://dx.doi.org/10.37149/jia.v5i3.12304

Received: June 06, 2020; Accepted: June 27, 2020; Published: June 30, 2020

\begin{abstract}
A partnership is a business strategy that is cultivated in a cooperative relationship between two or more parties with each other's principles of need, raising, and mutual benefit. The goal is to know the impact of partnerships formed between farmers partners with Aspakusa Makmur Association, know the influence of partnership factors namely communication, cooperation, trust, commitment, and conflict on the social partnership conditions of farmers partners and Aspakusa Makmur Association and know the influence of acceptance, experience, land tenure, and relationship value to the economic partnership condition of farmers partner and Aspakusa Makmur Association. The research methods used are surveys. Sampling using a simple random sampling technique of 53 respondents. The implementation of research started in January - February 2020. Data analysis uses descriptive analysis and multiple linear regression. The results showed that the partnership pattern formed as a general trade partnership pattern. Variable cooperation (X2) and commitment (X4) have a significant influence on the social partnership conditions (Y1), while the communication (X1), trust (X3), and conflict (X5) do not have a significant influence on the social partnership conditions (Y1). Variable acceptance $(\mathrm{X} 6)$ and relationship value $(\mathrm{X} 9)$ have a significant influence on the economic partnership conditions (Y2), while the experience (X7) and land tenure (X8) do not have a significant influence on the economic partnership conditions (Y2). The need to expand the market for increased sales and profits, it will increase the number of partner farmer supply and minimize the possibility of stacking and rejection of crop yields.
\end{abstract}

Keywords: agribusiness; aspakusa makmur association; partnership; socio-economic

\section{PENDAHULUAN}

Di Indonesia sektor pertanian, kehutanan, dan perikanan masih mendominasi lapangan pekerjaan di Indonesia. Penduduk Indonesia yang bekerja di sektor pertanian pada Februari 2018 sebesar 30,46\%, namun jumlah ini semakin menurun tiap tahunnya dibandingkan tahun sebelumnya sebesar 1,41\% (BPS, 2018). Sektor pertanian semakin ditinggalkan karena identik dengan kemiskinan. Jika jumlah tenaga kerja di sektor pertanian terus menurun tiap tahunnya, hal ini dapat berdampak pada meningkatnya jumlah impor produk pertanian dan krisis pangan nasional yaitu kondisi kelangkaan pangan di masyarakat.

Indonesia memiliki kesempatan untuk menjadi negara agribisnis terbesar dengan memanfaatkan peluang dari sisi penawaran pada pasar produk agribisnis internasional. Agribisnis Indonesia masih berada pada fase bertumbuh dan masih dapat terus tumbuh di masa yang akan datang, Indonesia juga memiliki sumberdaya alam yang mendukung untuk pertanian dan negaranegara pesaing Indonesia yang secara tradisional menguasai agribisnis internasional pemasalahan lahan di masa mendatang akan menjadi kesulitan utama untuk mengembangkan agribisnis.

Petani di Indonesia sampai sekarang masih didominasi skala ekonomi kecil yang disebabkan keterbatasan lahan, lemahnya pengetahuan, keterampilan, modal, dan teknologi. Di sektor tanaman pangan dan hortikultura, pengusahaan sayuran banyak diminati karena siklusnya yang pendek dan potensi pasar yang tinggi, dibandingkan dengan mengusahakan tanaman pangan seperti padi yang 
membutuhkan lahan yang luas dan siklus yang lebih lama. Dasar permasalahan petani sayuran yaitu kesalahan dalam penanganan pascapanen yang dapat menurunkan kualitas sayuran, kesulitan dalam akses memperoleh informasi pasar yang tepat, serta harga yang fluktuatif dan cenderung sangat rendah ketika musim panen berdampak pada kerugian petani. Masalah tersebut juga terjadi pada petani-petani sayuran di kabupaten Boyolali.

Kabupaten Boyolali, Jawa Tengah memiliki 19 kecamatan yang mengusahakan aneka jenis sayuran. Wilayah kabupaten Boyolali berupa dataran rendah dan dataran tinggi. Bagian barat Boyolali yaitu Ampel, Cepogo, Musuk, dan Selo berada di ketinggian sekitar 600 - 1500 mdpl ditandai dengan iklim yang sejuk, sehingga sesuai untuk pertanian sayuran (BPS Kabupaten Boyolali, 2018). Melihat peluang tersebut, pemerintah daerah Boyolali melakukan pengembangan agribisnis sayuran dengan mendatangkan ahli dari Taiwan untuk bekerjasama membina petani yang kemudian mendirikan Kelompok Agribisnis Aspakusa Makmur pada 1996. Aspakusa Makmur dibina dalam hal budidaya, pascapanen hingga pemasaran yang orientasi pasarnya adalah retail modern. Budidaya sayuran diarahkan menjadi komoditas yang komersil dengan tujuan memenuhi permintaan pasar. Setelah Taiwan Technical Mission selesai melakukan binaan pada November 2005. Aspakusa Makmur menjadi sebuah asosiasi yang beranggotakan para petani perorangan dan kelompok tani baik dataran rendah maupun dataran tinggi di daerah Boyolali dan sekitarnya. Asosiasi Aspakusa Makmur memiliki tugas untuk mengembangkan Misi Taiwan tidak hanya dari pemasaran sayuran tetapi juga kepentingan pengembangan dan kesejahteraan petani anggota asosiasi. Petani diintegrasi ke sektor yang lebih modern, yaitu industri. Apabila penanganan yang baik dimulai dari tahap on farm hingga off farm maka dapat meminimalisir kerugian bagi petani. Hal ini yang kemudian mendasari munculnya konsep kemitraan.

Kemitraan merupakan suatu hubungan atau jalinan kerjasama antara berbagai pelaku agribisnis dalam jangka waktu tertentu dengan prinsip saling membutuhkan, saling menguntungkan, dan saling menguatkan satu sama lain (Wahyudi, 2010). Kemitraan juga dapat dimaknai sebagai suatu bentuk persekuatan antara dua pihak atau lebih yang membentuk suatu ikatan kerjasama berdasarkan kesepakatan dan rasa saling membutuhkan untuk meningkatkan pendapatan, kesinambungan usaha, kuantitas produksi, kualitas produksi, meningkatkan kualitas kelompok mitra, dan meningkatkan kemampuan usaha kelompok mitra mandiri. Sistem kemitraan petani pada umumnya dilakukan dengan beberapa cara, misalnya dengan perjanjian kontrak kerjasama antara perusahaan mitra dengan petani. Selain itu, adapula kemitraan yang didasarkan atas dasar kepercayaan satu sama lain. Pada umumnya, kemitraan dilakukan antara kelompok tani dengan usaha kecil menengah atau industri kecil.

Menurut Rochmawan (2013), faktor yang menjadi penentu keberhasilan kemitraan petani dalam menjalankan kemitraan yaitu skala usaha, lama usaha, manajemen dan jumlah tenaga kerja. Dimensi kunci kemitraan menurut Boeck dan Wamba (2007) sebagai berikut: 1) Komunikasi yaitu berupa frekuensi dan kualitas aliran informasi antar pihak mitra, 2) Kerjasama yaitu kemauan melakukan tindakan untuk mencapai tujuan bersama, 3) Kepercayaan berupa keyakinan bahwa mitra dagang akan menjalankan kewajiban dan melakukan yang terbaik demi kepentingan mitra, 4) Komitmen yaitu keinginan untuk memastikan bahwa hubungan akan berkesinambungan, 5) Konflik yaitu ketidaksesuaian antara pihak mitra, dan 6) Hubungan nilai yaitu pilihan antara manfaat dan pengorbanan mengenai semua aspek dari hubungan.

Penelitian yang dilakukan Alam \& Hermawan (2017), komitmen berpengaruh dalam kemitraan karena kedua belah pihak berkomitmen untuk bekerjasama agar tercapai tujuan bersama, berkomunikasi untuk menjaga hubungan dan menjaga kepercayaan dengan baik. Menurut Sumardjo dkk., (2004) terdapat lima bentuk kemitraan yaitu pola kemitraan inti plasma, pola kemitraan subkontrak, pola kemitraan dagang umum, pola kemitraan keagenan dan pola kemitraan kerja sama operasional agribisnis (KOA).

Tujuan dari penelitian adalah untuk mengetahui pola kemitraan yang terbentuk antara petani mitra dengan Asosiasi Aspakusa Makmur, pengaruh faktor-faktor kemitraan terhadap kondisi sosial dan ekonomi petani mitra, dan pengaruh kemitraan terhadap kondisi sosial dan ekonomi Asosiasi Aspakusa Makmur.

\section{MATERI DAN METODE}

Penelitian ini dilaksanakan pada bulan Januari - Februari 2020 di Asosiasi Aspakusa Makmur Boyolali. Lokasi penelitian ditentukan secara purposive. Asosiasi Aspakusa Makmur dipilih karena merupakan sebuah kelompok agribisnis berupa asosiasi yang anggotanya adalah beberapa petani sayuran di daerah Boyolali. Populasi penelitian ini adalah petani mitra anggota Asosiasi Aspakusa Makmur sebanyak 112 orang. Penentuan jumlah sampel menggunakan rumus slovin (Sidharta et al., 
2017) diperoleh sampel sebanyak 53 orang petani dengan pengambilan sampel menggunakan teknik simple random sampling dan sampel pihak Asosiasi Aspakusa Makmur sebagai lembaga mitra.

Variabel dalam penelitian ini meliputi komunikasi $\left(X_{1}\right)$, kerjasama $\left(X_{2}\right)$, kepercayaan $\left(X_{3}\right)$, komitmen $\left(X_{4}\right)$ dan konflik $\left(X_{5}\right)$ digunakan untuk mengetahui pengaruh kemitraan terhadap kondisi sosial kemitraan $\left(Y_{1}\right)$. Variabel penerimaan petani $\left(X_{6}\right)$, pengalaman $\left(X_{7}\right)$, penguasaan lahan $\left(X_{8}\right)$ dan hubungan nilai $\left(X_{9}\right)$ digunakan untuk mengetahui pengaruh kemitraan terhadap kondisi ekonomi kemitraan $\left(\mathrm{Y}_{2}\right)$.

Pengaruh kemitraan terhadap petani mitra secara sosial dan ekonomi, diukur menggunakan lima Skala Likert yaitu Tidak Setuju (TS), Kurang Setuju (KS), Netral (N), Setuju (S), dan Sangat Setuju (SS). Data yang telah diperoleh diolah menggunakan analisis regresi linier berganda yang bertujuan untuk mengetahui pengaruh faktor-faktor kemitraan terhadap kondisi sosial dan ekonomi petani mitra. Analisis deskriptif digunakan untuk mengetahui pola kemitraan yang terbentuk dan mengetahui pengaruh faktor-faktor kemitraan terhadap kondisi sosial dan ekonomi lembaga mitra yaitu dengan menggambarkan atau melukiskan fakta-fakta, keadaan, ataupun gejala yang tampak dalam kemitraan ini.

\section{HASIL DAN PEMBAHASAN}

\section{Karakteristik Responden}

Karakteristik responden petani mitra Asosiasi Aspakusa Makmur meliputi jenis kelamin, usia, pendidikan, lama bermitra dan alasan bermitra yang dapat dilihat pada Tabel 1 .

Tabel 1. Karakteristik responden petani mitra Asosiasi Aspakusa Makmur

\begin{tabular}{llcc}
\hline \multicolumn{1}{c}{ Variabel } & Kategori & Frekuensi (orang) & Persentase (\%) \\
\hline Jenis kelamin & Laki-laki & 39 & 72 \\
& Perempuan & 15 & 28 \\
\hline Usia & $22-29$ tahun & 8 & 15 \\
& $30-37$ tahun & 7 & 13 \\
& $38-45$ tahun & 11 & 21 \\
& $46-53$ tahun & 11 & 21 \\
& $54-61$ tahun & 12 & 23 \\
& $62-69$ tahun & 2 & 4 \\
& $70-77$ tahun & 1 & 2 \\
& $>78$ tahun & 1 & 2 \\
\hline Pendidikan & SD & 7 & 13 \\
& SMP & 13 & 25 \\
& SMA & 25 & 47 \\
& Perguruan Tinggi/Akademik & 8 & 15 \\
\hline Lama bermitra & $2-4$ tahun & 8 & 15 \\
& $5-7$ tahun & 11 & 21 \\
& $8-10$ tahun & 16 & 30 \\
& $11-13$ tahun & 6 & 11 \\
& $14-16$ tahun & 6 & 11 \\
& $17-19$ tahun & 0 & 0 \\
& $20-22$ tahun & 3 & 6 \\
& $23-25$ tahun & 3 & 6 \\
\hline Alasan bermitra & Saran dari pemerintah & 0 & 0 \\
& Ajakan dari Asosiasi Aspakusa Makmur & 27 & 51 \\
& Diajak teman (petani lain) & 9 & 17 \\
& Inisiatif sendiri & 17 & 32 \\
\hline
\end{tabular}

Sumber: Data primer diolah, 2020

Data diatas menunjukkan bahwa tidak hanya laki-laki yang melakukan kegiatan usahatani dan bermitra dengan Asosiasi Aspakusa Makmur namun juga perempuan. Hal tersebut dikarenakan kegiatan usahatani tidak hanya merupakan pekerjaan utama tapi juga dijadikan sampingan untuk memperoleh tambahan penerimaan dan pemanfaatan pekarang rumah sebagai lahan budidaya. Menurut Syarif \& Zainuddin (2017), peran perempuan yang dapat diusahakan dalam pembangunan pertanian yaitu gerakan ketahanan pangan keluarga dan masyarakat melalui intensifikasi 
pemanfaatan lahan pekarangan. Selain itu, keterlibatan perempuan di sektor pertanian telah menjadi sesuatu yang wajar, mengingat mayoritas mata pencaharian penduduk di pedasaan adalah bertani.

Usia responden mayoritas berada pada rentang usia 54-61 tahun, sedangkan usia terendah berada pada rentang usia lebih dari 70 tahun. Menurut Nurhasikin dalam Alam \& Hermawan (2017) rentang usia produktif yaitu antara 15 - 64 tahun. Hal tersebut menunjukkan bahwa mayoritas responden petani mitra di Asosiasi Aspakusa Makmur berada dalam usia produktif. Namun dalam penelitian ini produktif atau non produktifnya usia petani tidak mempengaruhi petani untuk bermitra dengan Asosiasi Aspakusa Makmur.

Petani mitra terbanyak memiliki jenjang pendidikan SMA, sedangkan jenjang pendidikan SD terendah jumlahnya. Menurut Notoatmojo dalam Alam \& Hermawan (2017), tingkat pendidikan membantu individu dalam menyerap dan memahami pengetahuan yang diperoleh, pada umumnya semakin tinggi pendidikan seseorang maka semakin baik pula kemampuannya. Oleh karena itu, diharapkan informasi yang diberikan oleh Asosiasi Aspakusa Makmur dapat diterima dengan baik oleh petani mitra.

Mayoritas petani memilih bergabung menjadi mitra karena ajakan dari Asosiasi Aspakusa Makmur. Asosiasi Aspakusa Makmur pada awal berdiri memang lebih banyak mengajak petani secara langsung untuk bermitra dengan mereka karena petani merupakan stakeholder terpenting dalam berlangsungnya usaha ini.

\section{Pola Kemitraan Antara Petani Mitra dengan Asosiasi Aspakusa Makmur}

Pola kemitraan yang terbentuk antara petani dengan Asosiasi Aspakusa Makmur merupakan pola kemitraan dagang umum, namun tidak secara murni karena dibarengi dengan pengembangan petani mitra. Menurut Sumardjo, dkk. dalam Alam \& Hermawan (2017), dalam pola kemitraan dagang umum, petani yang tergabung dalam suatu kelompok berperan sebagai pemasok yang menjual hasil panennya ke lembaga mitra berdasarkan kuantitas dan standar kualitas tertentu yang telah disepakati. Keunggulan dalam pola kemitraan ini adalah petani mitra dapat menjual hasil panennya kepada lembaga mitra dan lembaga mitra dapat memperoleh pasokan dengan standar kualitas yang diharapkan untuk dapat dipasarkan ke supermarket. Keuntungan dari pola kemitraan ini berasal dari marjin harga, jaminan harga produk yang diperjualbelikan, dan jaminan mutu produk yang disesuaikan dengan kesepakatan antara pihak yang bermitra. Berdasarkan penelitian yang dilakukan Umyati (2019), jaminan harga memberikan pengaruh yang positif terhadap pendapatan usahatani, hal tersebut dikarenakan petani merasa dengan kemitraan mereka menjadi aman dari fluktuasi harga, terutama saat harga di pasar sedang turun drastis.

Petani mitra bertugas memasok hasil panennya ke Asosiasi Aspakusa Makmur dalam kemitraan ini. Hasil panen ini merupakan bahan baku yang oleh Asosiasi Aspakusa Makmur akan diproses dan dikemas untuk kemudian dipasarkan ke berbagai supermarket yang telah bekerjasama dengan Asosiasi Aspakusa Makmur. Dalam penelitian Pasaribu dkk. (2013), implementasi dari kemitraan adalah petani menjadi produsen lalu hasil panen dikumpulkan dan diproses oleh lembaga mitra yang kemudian menjadi produk yang lebih baik untuk dipasarkan.

Dalam kemitraan antara Asosiasi Aspakusa Makmur dengan petani mitra tidak terdapat kontrak tertulis karena sistem yang dijalankan adalah kekeluargaan dengan asas kepercayaan. Petani mitra disini merupakan anggota asosiasi, sehingga selain pemasaran ada juga penyuluhan atau pendampingan untuk pengembangan petani mitra oleh Asosiasi Aspakusa Makmur. Penyuluhan dan pendampingan yang dilakukan oleh Asosiasi Aspakusa Makmur yaitu tentang penanganan pasca panen yang baik, sehingga produk-produk yang berkualitas mampu terjaga kualitasnya hingga saat produk dipasarkan. Asosiasi Aspakusa Makmur juga mengenalkan komoditas-komoditas baru yang jarang ditanam oleh petani tradisional, yaitu komoditas yang biasanya hanya ada di supermarket seperti asparagus, kucai daun, bayam merah, okra, daun ketumbar, lobak, zukini, kol merah, dan sayuran lainnya.

\section{Pengaruh Komunikasi, Kerjasama, Kepercayaan, Komitmen dan Konflik Terhadap Kondisi Sosial Kemitraan Petani Mitra}

Hasil analisis regresi linear berganda pengaruh komunikasi, kerjasama, kepercayaan, komitmen dan konflik terhadap kondisi sosial kemitraan petani mitra pada penelitian ini dapat dilihat pada Tabel 2. Hasil uji $F$ diperoleh variabel komunikasi $\left(X_{1}\right)$, kerjasama $\left(X_{2}\right)$, kepercayaan $\left(X_{3}\right)$, komitmen $\left(\mathrm{X}_{4}\right)$, dan konflik $\left(\mathrm{X}_{5}\right)$ secara simultan berpengaruh terhadap kondisi sosial kemitraan $\left(\mathrm{Y}_{1}\right)$ petani mitra Asosiasi Aspakusa Makmur. Nilai adjusted $R$ Square $\left(R^{2}\right)$ sebesar 0,669 yang berarti bahwa kondisi sosial kemitraan $\left(Y_{1}\right)$ petani mitra dipengaruhi oleh variabel komunikasi $\left(X_{1}\right)$, kerjasama $\left(X_{2}\right)$, kepercayaan $\left(X_{3}\right)$, komitmen $\left(X_{4}\right)$, dan konflik $\left(X_{5}\right)$ sebesar $66,9 \%$, sedangkan sisanya sebesar $33,1 \%$ dipengaruhi oleh variabel lain diluar model penelitian. Dalam suatu hubungan 
kemitraan, peran kedua belah pihak mitra tentu sangat dibutuhkan untuk memperoleh dampak yang positif. Hal ini didukung oleh Manalu \& Mulyani (2018) dalam penelitiannya yang menyatakan bahwa proses kemitraan dapat terlaksana dengan baik jika ditunjang oleh adanya kelengkapan perencanaan, meliputi aspek pemasaran, pembinaan, dan teknologi. Pemberian pelatihan-pelatihan akan menciptakan interaksi dan berujung pada perubahan sosial (Andriani et al., 2019).

Tabel 2. Hasil uji analisis regresi linier berganda pada $Y_{1}$

\begin{tabular}{lcrcc}
\hline Variabel Penelitian & Koefisien Regresi $(\mathrm{B})$ & Std. Error & t-test & Signifikansi \\
\hline Constant) & 1,437 & 6,681 & 0,215 & 0,831 \\
Komunikasi $\left(X_{1}\right)$ & 0,187 & 0,159 & 1,173 & $0,247^{\text {ns }}$ \\
Kerjasama $\left(X_{2}\right)$ & 0,928 & 0,274 & 3,381 & $0,001^{*}$ \\
Kepercayaan $\left(X_{3}\right)$ & 0,392 & 0,373 & 1,050 & $0,299^{\text {ns }}$ \\
Komitmen $\left(X_{4}\right)$ & 1,629 & 0,450 & 3,623 & $0,001^{*}$ \\
Konflik $\left(X_{5}\right)$ & $-0,043$ & 0,306 & $-0,140$ & $0,889^{\text {ns }}$ \\
\hline$F_{\text {hitung }}$ & 22,007 & $t_{\text {tabel }}$ & 2,0117 & \\
$R$ & 0,837 & & & \\
$R$-square & 0,701 & & & \\
Adjusted $R$-square & 0,669 & & & \\
\hline
\end{tabular}

Keterangan: * Nyata pada signifikansi $5 \%(0,05){ }^{\text {ns }}$ Non signifikasi

Sumber: Data primer diolah, 2020

Hasil uji $t$ diketahui bahwa hanya variabel kerjasama $\left(X_{2}\right)$ dan komitmen $\left(X_{4}\right)$ yang berpengaruh secara parsial terhadap kondisi sosial kemitraan petani mitra, sedangkan variabel komunikasi $\left(X_{1}\right)$, kepercayaan $\left(X_{3}\right)$ dan konflik $\left(X_{5}\right)$ tidak berpengaruh. Hasil penelitian yang diperoleh Alam \& Hermawan (2017) menunjukkan bahwa hanya variabel komitmen yang berpengaruh dalam kemitraan, sedangkan komunikasi, kerjasama dan kepercayaan tidak. Dalam hubungan kemitraan antara petani dengan Asosiasi Aspakusa Makmur, kerjasama yang terjalin merupakan suatu hubungan simbiosis mutualisme, yaitu saling menguntungkan. Petani mitra memperoleh manfaat pemasaran yang baik dan harga yang tinggi serta informasi mengenai teknologi dan inovasi pertanian yang baru sedangkan Asosiasi Aspakusa Makmur mendapat ketersediaan pasokan bahan baku sayuran yang berkualitas. Hal ini sesuai dengan teori Johnson (2010), yang menyatakan bahwa setiap bagian kelompok saling berhubungan sedemikian rupa sehingga pengetahuan yang dimiliki seseorang akan menjadi output bagi yang lain dan output ini akan menjadi input bagi yang lainnya. Qonita (2012) dalam penelitiannya juga menyatakan bahwa kerjasama saling menguntungkan yang berkesinambungan akan mewujudkan kesejahteraan sosial petani dan ketenangan berusaha bagi pengusaha mitra. Komitmen yang diterapkan disini adalah komitmen petani untuk memenuhi kebutuhan Asosiasi Aspakusa Makmur dan kebersediaan melanjutkan kemitraan dengan Asosiasi Aspakusa Makmur. Hal tersebut didukung oleh teori Rahman (2015), yang menyatakan bahwa keberlangsungan kerjasama kemitraan sangat bergantung kepada seberapa kuat komitmen diantara pihak yang bermitra. Romdhon \& Sukiyono (2011) menyatakan bahwa keinginan dan perilaku sedikit banyak akan berpengaruh dalam kemitraan. Komitmen kedua belah pihak mitra untuk saling bekerjasama dengan baik untuk mencapai tujuan bersama, berkomunikasi dengan baik untuk menjaga hubungan dan kepercayaan antara kedua belah pihak mitra (Alam \& Hermawan, 2017).

\section{Pengaruh Penerimaan, Pengalaman, Penguasaan Lahan dan Hubungan Nilai Terhadap Kondisi Ekonomi Kemitraan Petani Mitra}

Hasil analisis regresi linear berganda untuk mengetahui pengaruh faktor-faktor kemitraan yaitu penerimaan petani $\left(X_{6}\right)$, pengalaman $\left(X_{7}\right)$, penguasaan lahan $\left(X_{8}\right)$, dan hubungan nilai $\left(X_{9}\right)$ terhadap kondisi ekonomi kemitraan $\left(Y_{2}\right)$ petani mitra dapat dilihat pada Tabel 3. Hasil uji $F$ diketahui bahwa variabel penerimaan petani $\left(X_{6}\right)$, pengalaman $\left(X_{7}\right)$, penguasaan lahan $\left(X_{8}\right)$ dan hubungan nilai $\left(\mathrm{X}_{9}\right)$ secara simultan (bersama-sama) memiliki pengaruh terhadap kondisi ekonomi kemitraan $\left(\mathrm{Y}_{2}\right)$ petani mitra. Nilai adjusted $R$ Square $\left(R^{2}\right)$ menunjukkan kondisi ekonomi kemitraan $\left(Y_{2}\right)$ petani mitra dipengaruhi oleh variabel penerimaan petani $\left(X_{6}\right)$, pengalaman $\left(X_{7}\right)$, penguasaan lahan $\left(X_{8}\right)$ dan hubungan nilai $\left(X_{9}\right)$ sebesar $31,2 \%$, sedangkan sisanya sebesar $68,8 \%$ dipengaruhi oleh variabel lain diluar model penelitian.

Hasil uji t diketahui bahwa variabel penerimaan petani $\left(X_{6}\right)$ dan hubungan nilai $\left(X_{9}\right)$ berhubungan secara parsial terhadap kondisi ekonomi kemitraan petani mitra, sedangkan variabel pengalaman $\left(X_{7}\right)$ dan penguasaan lahan $\left(X_{8}\right)$ tidak berpengaruh. Penerimaan petani mitra diperoleh dari hasil penjualan hasil panennya. Selisih harga yang diberikan Asosiasi Aspakusa Makmur lebih tinggi antara $20 \%$ - 100\% dari harga di pasar tradisional. Petani mitra rata-rata memperoleh 
penerimaan $R p 100.000$ - Rp 1.000 .000 setiap minggunya. Penerimaan ini tentu bukan penjualan total hasil panen petani mitra, tetapi hanya penerimaan yang diterima dari penjualan di Asosiasi Aspakusa Makmur yang biasanya hanya sekitar $30 \%$ dari total hasil panen petani mitra. Petani mitra berharap dapat menjual hasil panennya kepada Asosiasi Aspakusa Makmur lebih banyak karena harga yang diberikan sangat menguntungkan petani. Namun, jumlah setoran ini dipengaruhi oleh beberapa hal seperti jumlah permintaan dari supermarket, kualitas hasil panen, dan petani mitra lain. Penerimaan petani merupakan salah satu penentu besar pendapatan petani. Hal ini sejalan dengan penelitian yang dilakukan Zaini (2010), bahwa penerimaan berpengaruh secara signifikan terhadap pendapatan.

Tabel 3. Hasil uji analisis regresi linier berganda pada $\mathrm{Y}_{2}$

\begin{tabular}{lcccc}
\multicolumn{1}{c}{ Variabel Penelitian } & Koefisien Regresi $(\mathrm{B})$ & Std. Error & t-test & Signifikansi \\
\hline (Constant) & 7,546 & 3,477 & 2,170 & 0,035 \\
Penerimaan Petani $\left(\mathrm{X}_{6}\right)$ & 2,396 & 0,000 & 3,161 & $0,003^{*}$ \\
Pengalaman $\left(\mathrm{X}_{7}\right)$ & $-0,039$ & 0,033 & $-1,164$ & $0,250^{\text {ns }}$ \\
Penguasaan Lahan $\left(\mathrm{X}_{8}\right)$ & $-7,695$ & 0,000 & $-0,304$ & $0,763^{\text {ns }}$ \\
Hubungan Nilai $\left(\mathrm{X}_{9}\right)$ & 0,558 & 0,221 & 2,527 & $0,015^{*}$ \\
\hline$F_{\text {hitung }}$ & 6,902 & t-tabel & 2,0106 & \\
R & 0,604 & & & \\
$R$-square & 0,365 & & & \\
Adjusted $R$-square & 0,312 & & & \\
Keterangan * ${ }^{*}$ Nyata pada signifikansi $5 \%(0,05)$ & & &
\end{tabular}

Keterangan: * Nyata pada signifikansi $5 \%(0,05) \quad{ }^{\text {ns }}$ Non signifikasi

Sumber: Data primer diolah, 2020

Hasil penelitian ini diketahui bahwa pengalaman tidak berpengaruh terhadap kondisi ekonomi kemitraan petani. Asosiasi Aspakusa Makmur membutuhkan produk yang memiliki kualitas yang tinggi dan juga memiliki tujuan untuk mengembangkan pertanian daerah. Oleh sebab itu, lama petani dalam berusahatani tidak menjadi perhatian bagi Asosiasi Aspakusa Makmur. Hoar \& Fallo (2017) dalam penelitiannya menyatakan bahwa petani yang telah lama menjalankan usahatani lebih dari 20 tahun sulit menerima inovasi baru yang dapat meningkatkan produksi. Petani biasanya lebih nyaman dengan kondisi usahatani yang telah dijalankan bertahun-tahun. Namun, hal tersebut juga tidak menutup kesempatan bermitra dengan petani yang telah memiliki pengalaman cukup lama. Gustiana \& Irwanto (2017) menyatakan pengalaman petani juga sangat menunjang kemampuan untuk mengadopsi teknologi dalam usahanya dikarenakan pola pikir yang semakin luas seiring dengan lamanya pengalaman berusahatani.

Dengan visi meningkatkan kesejahteraan petani melalui produksi hortikultura premium, Asosiasi Aspakusa Makmur sungguh menjadikan petani sebagai bagian penting dalam kemitraan ini. Pembinaan dan pelatihan yang diberikan membantu petani untuk mengatasi masalah terkait kegiatan usahatani dengan lebih mudah. Hubungan kemitraan ini juga memotivasi petani dalam berusahatani untuk mampu menghasilkan hasil panen yang berkualitas dan berharga tinggi. Menurut Saida dkk. (2011), komoditas unggulan dengan produktivitas yang tinggi dan harga jual yang tinggi serta ketersediaan pemasaran maka akan meningkatkan pendapatan petani. Demikian pula dengan pengelolaan pasca panen akan berpengaruh pada kualitas hasil. Apabila pengelolaannya baik maka kualitas hasil sayuran akan baik pula sehingga nilai jualnya akan meningkat. Selain itu, petani mitra juga dilibatkan dalam pembuatan kebijakan terkait kemitraan, sehingga petani juga merasakan manfaat secara nyata. Penelitian yang dilakukan Erick (2010) diketahui hubungan merupakan suatu proses, cara atau arahan yang membawa dampak atau pengaruh. Hal tersebut membuat petani merasakan manfaatnya dalam kondisi perekonomian petani.

\section{Pengaruh Komunikasi, Kerjasama, Kepercayaan, Komitmen dan Konflik Terhadap Kondisi Sosial Kemitraan Lembaga Mitra}

Sebagai sebuah usaha yang berada di sektor pertanian yaitu sortasi dan pengemasan sayuran dengan tujuan pasar adalah supermarket, membuat Asosiasi Aspakusa Makmur membutuhkan pasokan bahan baku yang segar dan berkualitas. Dalam rangka memastikan pemenuhan kebutuhan bahan baku tersebut maka Asosiasi Aspakusa Makmur menjalin kemitraan dengan petani di daerah sekitar Boyolali. Selain itu, yang melatarbelakangi Aspakusa Makmur untuk menjalin kemitraan dengan petani yaitu keinginan untuk mengenalkan jenis-jenis sayuran baru, meningkatkan kesejahteraan petani, membudidayakan sayuran yang bernilai ekonomi tinggi dan mengenalkan tentang pentingnya pemasaran bersama kepada petani. Hal ini yang memunculkan suatu kondisi sosial dan ekonomi dalam hubungan kemitraan ini. 
Asosiasi Aspakusa Makmur setuju bahwa komunikasi, kerjasama, kepercayaan, dan komitmen berpengaruh terhadap kondisi sosial kemitraan lembaga. Dalam membangun kemitraan yang baik, sistem kepercayaan diterapkan tanpa adanya kontrak tertulis antara pihak bermitra, sehingga bagi kedua belah pihak kemitraan ini bukan atas tekanan tetapi tanggung jawab. Hal ini diperkuat dengan komitmen petani mitra yang berpengaruh terhadap kondisi sosial kemitraan petani mitra. Asosiasi Aspakusa Makmur dalam kemitraan ini sadar akan perlunya adopsi dan penerapan teknologi dibidang pertanian. Adopsi dan penerapan teknologi yang selama ini telah diterapkan Asosiasi Aspakusa Makmur antara lain, teknologi budidaya sayuran baru, teknologi penanganan pasca panen dan teknologi pencucian dengan generator ozon. Kemitraan ini juga membuat adanya jaminan rasa aman bagi Asosiasi Aspakusa Makmur karena adanya jaminan bahan baku baik secara kualitas maupun kuantitas. Hal-hal tersebutlah yang kemudian menciptakan suatu kondisi sosial di Asosiasi Aspakusa Makmur.

Komunikasi, kerjasama, kepercayaan dan komitmen merupakan dimensi kunci dalam suatu kemitraan sesuai dengan teori Boeck \& Wamba (2007), sehingga sesuai jika komunikasi, kerjasama, kepercayaan dan komitmen berpengaruh dalam kondisi sosial kemitraan. Namun konflik yang merupakan ketidaksesuaian antara pihak mitra tidak berpengaruh terhadap kondisi sosial kemitraan. Adanya konflik dalam suatu hubungan kemitraan tentu dapat menciptakan suatu kondisi yang mempersulit suatu hubungan dan akan bertolak belakang dengan komunikasi, kerjasama, kepercayaan dan komitmen yang telah terjalin.

Keberhasilan Asosiasi Aspakusa Makmur dalam membangun hubungan kemitraan dengan petani mitra tersebut diperkuat dengan penelitian Saptana dkk. (2007), bahwa keberhasilan hubungan terletak pada pengambilan keputusan yang berada dalam satu managemen, kemampuan membangun kepercayaan, perekrutan melalui proses sosial dan seleksi yang ketat serta memiliki segmentasi pasar yang khusus. Qonita (2012) dalam penelitiannya menyebutkan bahwa kerjasama saling menguntungkan yang berkesinambungan akan mewujudkan ketenangan berusaha bagi pengusaha mitra.

\section{Pengaruh Penerimaan, Pengalaman, Penguasaan Lahan dan Hubungan Nilai Terhadap Kondisi Ekonomi Kemitraan Lembaga Mitra}

Kemitraan merupakan salah satu faktor penting dalam keberlangsungan usaha Asosiasi Aspakusa Makmur karena tanpa adanya kemitraan, Asosiasi Aspakusa Makmur akan mengalami kesulitan untuk memenuhi kebutuhannya. Asosiasi Aspakusa Makmur setuju bahwa penerimaan, pengalaman penguasaan lahan usaha dan hubungan nilai berpengaruh terhadap kondisi ekonomi kemitraan. Dengan jumlah rata-rata pesanan sebanyak $300 \mathrm{~kg}-500 \mathrm{~kg}$ tiap harinya tentu mempengaruhi kondisi ekonomi kemitraan karena penerimaan inilah yang akan menghidupkan kegiatan produksi dan membuat kemitraan ini terus berjalan. Hal ini sesuai dengan penelitian yang dilakukan Saptana dkk. (2007), bahwa melalui kemitraan, lembaga mitra mampu menyediakan sayuran yang dapat memenuhi jenis, volume, mutu dan kontinuitas pasokan dengan standar yang telah ditetapkan oleh pembeli dalam hal ini supermarket.

Asosiasi Aspakusa Makmur sendiri yang telah berdiri sejak 1996 berada dibawah bimbingan Misi Taiwan hingga berubah menjadi sebuah Asosiasi Aspakusa Makmur pada 2007. Dengan manajemen yang baik tentu membuat Asosiasi Aspakusa Makmur dapat terus berdiri hingga sekarang. Asosiasi Aspakusa Makmur telah bekerjasama dengan 11 supermarket di Jawa Tengah dan Jawa Timur. Hubungan nilai yang terjalin yaitu Asosiasi Aspakusa Makmur mampu mengatasi masalah terkait kekurangan pasokan sayuran, keinginan untuk terus berkembang, kesediaan untuk selalu melibatkan petani mitra dalam pembuatan kesepakatan dan meningkatkan nilai Asosiasi Aspakusa Makmur bagi petani mitra menjadi motivasi bagi Asosiasi Aspakusa Makmur yang kemudian berdampak pada kondisi ekonomi petani mitra.

Kemitraan ini juga membuat Asosiasi Aspakusa Makmur mampu membeli alat transportasi sendiri seperti mobil box pendingin dan motor roda tiga yang digunakan untuk membawa sayuran. Kemitraan ini juga membuat Asosiasi Aspakusa Makmur mampu memberikan jaminan gaji bagi karyawannya serta tunjangan bagi karyawan. Kemitraan yang tidak hanya bertujuan untuk mensejahterakan lembaga mitra tetapi juga mensejahterakan petani mitra membuat Asosiasi Aspakusa Makmur menerima beberapa bantuan dari pemerintah daerah untuk menunjang keberlangsungan usaha ini antara lain, hibah traktor dan traktor tangan, serta pinjaman gedung dan Iahan usaha dari Pemerintah Daerah Boyolali. Hal-hal tersebut yang kemudian menciptakan suatu kondisi ekonomi di Asosiasi Aspakusa Makmur. Pengaruh kemitraan yang dirasakan oleh Asosiasi Aspakusa Makmur didukung Qonita (2012), yang menyatakan manfaat ekonomi dari kemitraan antara lain, adanya jaminan pasokan bahan baku, meningkatnya pendapatan perusahaan mitra, dan meningkatkan pengembangan serta kemandirian usaha. 


\section{KESIMPULAN DAN SARAN}

Pola kemitraan yang terbentuk merupakan pola kemitraan dagang umum yang dibarengi dengan pengembangan petani mitra. Petani mitra berperan sebagai pemasok bagi lembaga mitra dengan kuantitas dan standar tertentu yang telah disepakati. Variabel yang mempengaruhi kondisi sosial kemitraan petani mitra adalah kerjasama dan komitmen. Kerjasama saling menguntungkan yang berkesinambungan akan mewujudkan kesejahteraan sosial petani dan ketenangan berusaha bagi pengusaha mitra. Namun, keberlangsungan kerjasama kemitraan sangat bergantung kepada seberapa kuat komitmen diantara pihak yang bermitra, sehingga kerjasama dan komitmen harus sejalan. Kemudian, variabel yang mempengaruhi kondisi ekonomi kemitraan petani mitra adalah penerimaan dan hubungan sosial. Hubungan kemitraan memotivasi petani dalam berusahatani untuk mampu menghasilkan hasil panen yang berkualitas dan berharga tinggi. Jaminan harga memberikan pengaruh yang positif terhadap perekonomian petani. Petani merasa dengan kemitraan mereka menjadi aman dari fluktuasi harga.

Asosiasi Aspakusa Makmur setuju bahwa kondisi sosial kemitraan lembaga dipengaruhi oleh komunikasi, kerjasama, kepercayaan dan komitmen. Asosiasi Aspakusa Makmur juga setuju bahwa kondisi ekonomi kemitraan lembaga dipengaruhi oleh penerimaan, pengalaman, penguasaan lahan dan hubungan sosial. Kemitraan ini memberikan jaminan kepada lembaga mitra yang dapat berujung pada kemandirian usaha.

Petani diharapkan untuk dapat memperhatikan faktor-faktor kemitraan lain dan melaksanakan kesepakatan yang telah dibuat, sehingga menjaga hubungan kemitraan yang akan berdampak pada kondisi sosial dan ekonomi petani mitra. Lembaga mitra diharapkan untuk memperhatikan kebutuhan petani dan memperluas cakupan pasarnya demi adanya peningkatan penjualan dan keuntungan, sehingga meningkatkan jumlah setoran petani mitra dan memperkecil kemungkinan adanya penumpukan serta penolakan hasil panen. Kemitraan sebaiknya terus dikembangkan di daerahdaerah terutama daerah dengan mata pencaharian utama penduduknya adalah petani. Hal ini untuk mendukung perkembangan perekonomian dalam sektor pertanian. Melihat bahwa kemitraan yang baik mampu memberikan pengaruh positif baik secara sosial dan ekonomi kepada pihak-pihak yang telibat dalam kemitraan tersebut.

\section{REFERENSI}

Alam, A.S. \& Hermawan, H. 2017. Faktor-faktor yang mempengaruhi hubungan kemitraan antara petani budidaya jamur tiram dengan cv. asa agro corporation. Agroscience, 7(1): 214-219.

Andriani, L.A., Windia, I.W. \& Ustriyana, I.N.G. 2019. Dampak sosial-ekonomi kemitraan KUD tani makmur dengan PT. nestle indonesia (studi kasus di desa kandang tepus, kecamatan senduro, kabupaten lumajang). Agribisnis dan Agrowisata, 8(3): 301-310. https://ojs.unud.ac.id/index.php/JAA/article/view/54716/32390.

Badan Pusat Statistik Kabupaten Boyolali 2018. Kabupaten Boyolali Dalam Angka. Boyolali: Badan Pusat Statistik.

Boeck, H. \& Wamba, S. 2007. RFID and buyer-seller relationships in the retail supply chain. International Journal of Retail \& Distribution Management, 36: 433-460.

BPS 2018. Keadaan ketenagakerjaan indonesia februari 2018. Badan Pusat Statistik, (42/05/Th. $\mathrm{XXI}): 1-16$.

Erick, S. 2010. Hubungan eksekutif desa dengan legislatif desa dalam penetapan peraturan desa tentang pembangunan fisik desa marga kaya. Skripsi Universitas Lampung.

Gustiana, C. \& Irwanto, I. 2017. Pengaruh biaya produksi, pengalaman, dan keterampilan terhadap pendapatan usahatani kakao (Theobroma cacao) di kecamatan karang baru kabupaten aceh tamiang. Jurnal Penelitian Agrisamudra, 4(2): 67-76.

Hoar, E. \& Fallo, Y.M. 2017. Pengaruh faktor sosial ekonomi petani terhadap produksi usahatani jagung di desa badarai kecamatan wewiku kabupaten malaka. AGRIMOR, 2(3): 36-38.

Johnson, E.B. 2010. Contextual teaching and learning: Menjadikan kegiatan belajar mengajar mengasyikkan dan bermakna (Terjemahan Setiawan Ibnu). Kaifa.

Manalu, D.S.T. \& Mulyani 2018. Kemitraan agribisnis tomat (studi kasus kelompok usahatani mekar tani jaya di lembang, jawa barat). Agrica Ekstensia, 12(1): 13-18. https://polbangtanmedan.ac.id/upload/upload/jurnal/Vol 12-1/03.

Pasaribu, A.I., Hasanuddin, T. \& Nurmayasari, I. 2013. Pola kemitraan dan pendapatan usahatani kelapa sawit: kasus kemitraan usahatani kelapa sawit antara PT Perkebunan Nusantara VII unit usaha Bekri dengan petani mitra di Desa Tanjung Jaya, Kecamatan Bangun Rejo, Kabupaten Lampung Tengah. Jurnal IImu-IImu Agribisnis, 1(4): 358-367. 
http://jurnal.fp.unila.ac.id/index.php/JIA/article/view/712/654.

Qonita, A. 2012. Motivasi kerja utama petani dalam kemitraan dengan pusat pengolahan kelapa terpadu di kabupaten kulon progo. SEPA, 9(1): 90-99.

Rahman, A. 2015. Komitmen pelaku kemitraan terhadap efisiensi dan keberlanjutan usahatani kelapa sawit plasma. Prosiding Seminar Nasional Lahan Suboptimal 2015. Palembang. http://www.pur-plso.unsri.ac.id/userfiles/47_Rahman2015.pdf.

Rochmawan, S. 2013. Pengaruh pola kemitraan dengan pt.bisi terhadap pendapatan petani jagung di kecamatan banyakan kabupaten kediri. Jurnal MANAJEMEN AGRIBISNIS, 13: 45-53.

Romdhon, M.M. \& Sukiyono, K. 2011. Pola kemitraan pemasaran lobster di kota bengkulu. Jurnal AGRISEP, 10(1): 126-137.

Saida, S., Sabiham, S., Widiatmaka, W. \& Sutjahjo, S.H. 2011. Analisis keberlanjutan usahatani hortikultura sayuran pada lahan berlereng di hulu das jeneberang, sulawesi selatan. Jurnal Matematika Sains dan Teknologi, 12(2): 101-112.

Saptana, S., Indraningsih, K.S. \& Hastuti, E.L. 2007. Analisis kelembagaan kemitraan usaha di sentra sentra produksi sayuran (suatu kajian atas kasus kelembagaan kemitraan usaha di bali, sumatera utara, dan jawa barat). SOCA: Jurnal Sosial Ekonomi Pertanian, 7(3). https://www.neliti.com/publications/44050/analisis-kelembagaan-kemitraan-usaha-di-sentrasentra-produksi-sayuran-suatu-kaj.

Sidharta, N.R., Sudarma, I.M. \& Djelantik, A.A.. W.S. 2017. Analisis efisiensi teknis penggunaan pupuk dan pestisida budidaya asparagus di desa pelaga, kecamatan petang, kabupaten badung. Jurnal Agribisnis dan Agrowisata (Journal of Agribusiness and Agritourism).

Sumardjo, Sulaksana, J. \& Darmono, W.A. 2004. Kemitraan Agribisnis. Jakarta: Penebar Swadaya.

Umyati, S. 2019. Pengaruh pola kemitraan terhadap pendapatan usahatani kentang (Solanum tuberosum L). Agrivet: Jurnal IImu-IImu Pertanian dan Peternakan (Journal of Agricultural Sciences and Veteriner), 7(1). https://jurnal.unma.ac.id/index.php/AG/article/view/1460.

Wahyudi 2010. Perbandingan pendapatan dari dua sistem kemitraan inti plasma yang berbeda pada usaha pembesaran ayam ras pedaging. MANAJEMEN IKM: Jurnal Manajemen Pengembangan Industri Kecil Menengah, 5(2): 111-121.

Zaini, A. 2010. Pengaruh biaya produksi dan penerimaan terhadap pendapatan petani padi sawah di loa gagak kabupaten kutai kartanegara. EPP, 7(1): 1-7. http://agb.faperta.unmul.ac.id/wpcontent/uploads/2017/04/jurnal-vol-7-no-1-zaini.pdf. 